DE DE GRUYTER

OPEN

U

DOI: 10.1515/aa-2015-0001

\title{
Surviving history: Kate Chopin
}

\author{
Kübra Baysal
}

Kübra Baysal has worked as an English instructor at Kastamonu University, Department of Foreign Languages, in Kastamonu, Turkey, since 2012. She graduated from Hacettepe University (Ankara), Department of English Language and Literature, in June 2008. She received her MA degree at Atatürk University, Department of English Language and Literature, in May 2013. She is now a PhD student at Hacettepe University (Ankara), Department of English Language and Literature. She is interested in ecofeminism, ecocriticism, posthumanism and the modern English novel. She has articles published in indexed journals, book translations and several conference presentations in the field of English literature and world literatures.

\begin{abstract}
Bearing witness to the colonial and anti-feminist atmosphere of $19^{\text {th }}$-century America, Kate Chopin created her works against a background of all kinds of repression reigning over social life. Likewise, Désirée's Baby focuses mainly on a young woman's marital life and the social/familial problems she confronts because of her personal background and imperial and gender-based oppression surrounding her life. Through a new historicist reading, the story has several humane elements to be taken into account. Reflecting the periphery and the repressed, Désirée's Baby is a significant anticanonical writing with an inspiring human touch and a historically excluded work which depicts the dramatic existential problems of the time.
\end{abstract}

\section{INTRODUCTION}

Even though she has not been as popular as other English and American writers, Kate Chopin is now considered one of the forerunners of postcolonial and feminist writing in $19^{\text {th }}$ - and $20^{\text {th }}$-century English and American literature. Apart from these attributions, Chopin's stories and novels are successful products of a combination of genius and art. She has reasonably distinct criticisms of $19^{\text {th }}$-century American society and thus reflects her distaste with the system by deep emotional description emanating from her feminine insight. She directs her arguments and ideas towards power in her highly sentimental and humane work Désirée's Baby. As Fred Louis Pattee puts it, Chopin's works are the representation of a unique talent and keen observation (Pattee, 1915, p. 364). Thence, through a genuine and striking piece of literature, Kate Chopin defies the norms and reflects the basic, ignored and sensational state of a young woman who suffers at the hands of the system only for revealing that she has black ancestors, which clearly places a human problem into the core of the argument. So, Chopin boldly comments on the state of the inferior and marginal of the time and their endeavours to overcome various obstacles, which happens to appeal to all humanity for it bears the "human touch". So, in this three-part study, a comprehensive inquisition of the story shall be made from a new historicist point of view, placing emphasis upon the marginalised point of view, thus reflecting the humane side of the story. In the first part, post-colonial, feminist and socialist approaches emphasised in the story are analysed whilst in the second part, Kate 
Chopin as a writer is the subject matter. The final part summarises the whole argument and concludes the study in reference to the new historicist perspective.

\section{NEW HISTORICIST SCOPE IN THE STORY}

New historicism is a school of literary theory and a reading method which was developed in the 1980s, fundamentally via the studies of Stephen Greenblatt, and became popular in the 1990s. The main argument of new historicism is that the literature and dominant culture of a specific period of time recorded by history are indeed the natural outcomes of various political, ideological and discursive forces dominating that period. Louis Montrose defines this aspect of history as historicity of texts and textuality of history, which means that literary texts are the representatives of particular periods, whereas history itself is a text formulated according to certain concepts (Pieters, 2001, p. 15). For this reason, new historicists believe that old historicism is a biased system in which knowledge is conveyed partially with a purpose and excluding the margin, the periphery and the different, such as women, black people and Jews. Further, Jürgen Pieters suggests that things failing to conform to the system are excluded or even regarded as non-existent, which causes the creation of a monolithic literature/history. Therefore, he says margins should be analysed in order to understand the centre, in which the margin includes the excluded groups of people with different and challenging opinions and minorities and their literary productions, whereas the centre covers the group of people who are supported and encouraged by the powerful authorities of the time for their conforming ideas and literary productions. Similarly, Gallagher and Greenblatt state that events called "anectodes" in new historicism representing a particular period much more effectively than other "well known" great events included in history are a good way to create a correct and honest history, which calls forth Désirée’s situation in the case of Chopin's story (2000, p. 37). Finally, traditional or old history includes relevant texts, whilst it ignores others and those outside the scope of literature completely, such as Kate Chopin's works. It makes classifications and distinctions as regards to significance which might function very discursively in the decision process (Lacapra, 1985, p. 126).

In the light of these new historical concepts, Désirée's Baby by Chopin can be studied as a marginal, postcolonial, feminist and socialist story of $19^{\text {th }}$-century America in three sections. Because postcolonialism deals with colonised communities, and feminism defends the rights of women who are repressed by society, and socialism is concerned with the side-effects of capitalism on people, these fields are accordingly included in New Historicism as studies of margin and the subject.

\section{A. Postcolonial Aspect}

Postcolonialism is a postmodern intellectual discourse that analyses and constitutes reactions against the cultural legacy of colonialism and colonial powers. It mostly consists of theories related to European countries that have dominated colonialism all over the world, such as the Caribbean, Rhode Island, Maryland and Plymouth in the Americas, and Ceylon in Asia. Postcolonialism primarily aims to eradicate the after-effects of colonialism from ex-colonised cultures and nations. One well-known postcolonial writer, Edward Said, puts forth the misrepresentation of the colonised Orient by the Occident, which represents the West in his Orientalism. As he says, the Orient as much as the Occident "is not an inert fact of nature. It is an idea that has a history and a tradition of thought, imagery and vocabulary that has given it reality and presence for the West (1978, p. 132). Postcolonialism as a field is enclosed in new historicism because it asserts the universal domination of Eurocentricism and the exclusion, repression and ignoration of this system towards everything else outside defined borders. It is also vindicated in postcolonial theory that European history can no longer be called a universal human history for there have emerged other histories and cultures after the 
decolonisation process in various parts of the world. In the 20th century, the European coloniser of the 19th century has realised the wrong partiality of their notion and tried to make amends for what they have done in the colonial period to those they have exploitated and oppressed (Chakrabarty, 2000, Introduction, p. 4). In other words, postcolonialism tries to compromise a universal umbrella frame which banishes any marginalisation and exclusion and uniting all nations and people of colour with humanity and the common points of simply being "human".

Thereto, an important colonial state of America, Louisiana, which hosted slave trading and importation in the 19th century makes up the setting of Kate Chopin's short story, Désirée's Baby. It is an important region of the southern part of the USA directly associated with landownership and slave labour of that period, which is why Chopin frames her plot around a postcolonial locality. Taking place in this colonial setting, the story consists of numerous colonial elements conveyed from a postcolonial perspective. Chopin makes many allusions to the colonial life in the state of Louisiana through Désirée's point of view.

If only briefly, the story starts with Désirée's mother's (Madame Valmondé) narration. Désirée is an adopted child, yet Madame Valmondé loves the girl as her own. She describes how she and her husband found Désirée by a rock sleeping all alone and left behind by her real parents. They decide to adopt the child and never regret it as she grows to be a pleasant, attractive young woman. Later on, a rich landowner, Armand Aubigny, falls in love with the girl and wants to marry her, whenupon Désirée's father tells him the truth about the young girl's unknown past; however, Armand is so passionate about marrying her that he does not care much about that. Consequently, Désirée and Armand are happily married and Désirée gets rid of her mysterious past via Armand's surname. Everything is so far so good between them. Then, the couple has a child, a son, who will uphold his father's name and ancestry. Armand is very proud of himself and his family, whilst Désirée is extremely happy. Nevertheless, she somehow feels that something terrible will occur in her family, for she is as happy as she has ever been before. Not much later, her fears come true when she realises her son's skin colour is dark, unlike hers. Armand is dark-skinned, still the child seems much darker than his father. This starts to worry Désirée because Armand hates black people. Some time later, the child grows enourmously which scares her more. As if this is not enough, the loving and passionate Armand of the past begins to avoid Désirée and the child like the plague. Interpreting her husband's behaviour and making speculations, Désirée decides to ask her husband directly what is wrong with him. Unfortunately, the answer is quite shocking for Désirée. In response, Armand only says the child is "black", making a disgusted face and blaming her for this because she is the one with an ambiguous past, implying that Désirée comes from a black family. She tries to prove she is pure white by showing him her ivory skin, fair hair and blue-grey eyes. Still, the husband is too blind to see. Being so desperately in love with Armand and stuck in a dilemma, Désirée writes her mother a letter asking for an explanation about her past and real family. However, after Madame Valmondé's response, she is even more confused because her mother tells Désirée to return to her father's house with her son. She says she welcomes them all sincerely. Hoping to change her husband's hostile attitude, she shows the letter to Armand. Yet, it encourages him to confess his real thoughts about Désirée and tells her to leave the house taking the baby with her and despite Désirée's facial expression and shock along with reluctance about leaving, he is genuinely determined. Disappointed with her husband and having no other purpose in life, Désirée takes the baby, leaves the house and disappears among the "negro" slaves into the unknown. The story ends pretty strikingly when Armand burns Désirée's and the baby's clothes and whatever is left from them and finds a letter among the belongings. This letter uncovers the whole mystery about Désirée's past and the "black skin factor" in the story. It is from Armand's mother addressed to his father and reveals that she is a slave who had a relationship with her white 
master. Hence, it is apparently understood that Armand has a black ancestry, not Désiréé, which leaves him puzzled and desperate as the story ends.

There are also postcolonial elements in the story to be examined. First of all, the story is based upon racial problems and the miscegenation of races. Black people working in Armand Aubigny's household and plantations are treated as slaves and are tortured, humiliated and scolded at any opportunity by the young master, Armand. Everyone serving at Armand's house is a black person or "negro" in colonialist Armand's words. He, as a land-owner and wealthy member of an imperial America, despises black people so much that he punishes them whenever he is angry with something, and he has no mercy or sympathy towards them. His excessive hatred towards these people is revealed once more when he notices his son's dark skin and becomes suspicious of his wife's ancestry. Even this unverified doubt is enough for him to get rid of Désirée and "her" baby. However, he is punished by poetic justice in the end when he discovers it is him with a black background because of his mother's family. He is responsible for the baby's dark skin, not Désirée. This puzzles him in the end as he thinks about himself and what he has done to his family, but it is no good because Désirée has already disappeared in desperation. Désirée also differentiates her son's skin colour from hers and realises the similarity with black people when a servant's child, a black boy, looks after his son. She looks at both boys and notices they are mostly alike which has a great effect on her life. Although she is not as prejudiced and hostile to black people as Armand and feels sympathy for them, she still becomes afraid when she associates his son with black people because she is living in a colonial country and time. Also, her husband is one of those fierce masters who denigrate the black slaves. As for miscegenation or the mixing of races, it is clearly seen in Armand Aubigny's mother and father's case. It is very common to witness interrelations between races, yet Armand is so prejudiced towards the other race that he cannot see he actually looks like them. Instead he tries subconsciously every aggressive move to torment them, as if he knows he is also one of them. However, no matter how hard he tries, the truth comes to the surface in the end and changes his life irreversibly. This miscegenation issue is also applicable to Désirée because she is thought both by her parents and her husband to be from a black family, as there is no certain evidence about her past. They consider this possibility based on her ambiguous background, yet the baselessness of this claim is acknowledged in the end when Armand realises he is just another human being of darkskinned origin.

What is more, Désirée's parents, Armand Aubigny and his family are representatives of the white race, imperialism and mastership, while the black folk are the embodiment of the black race, slavery and submission. At the beginning of the story, Madame Valmondé mentions a plantation near their house, which reveals her husband's colonial activities. Later on, Armand appears in the story as the son of a powerful, wealthy family, the Aubignys. The family is described as the "oldest and proudest" in Louisiana, again indicating the arrogance of the family against everyone else (Chopin, 1897, p. 1). After Madame's narration of the colonial lands and people, she arrives at the Aubignys' house to visit her daughter Désirée and her newborn son. The house is depicted as dark, gloomy and ragged because the "old master" is no longer at home. The house is now under young Armand's rule, which means the colonial exploitation in the house is maintained. The young master still commands the slaves to serve him and his family. As Madame explains, the young master is much stricter than his father, who had been quite kind and considerate to the workers. Afterwards, it is communicated by Désirée that Armand has not punished or humiliated the blacks since his baby son was born. His "imperious" mood has disappeared for days (Chopin, 1897, p. 2). He is extremely content and satisfied with the birth of his son. However, the blissful atmosphere in the household lasts a very short time, until Armand notices the baby's dark skin. When the baby is three months old, there is a tense and nervous atmosphere among the blacks, for they also notice the baby's 
resemblance to them. Désirée is scared, sensing approaching disaster in the house because Armand acts strangely and menacingly towards black people. Later one afternoon, Désirée is resting inside, with her baby tended by one of the female servant's little sons. Here, the imperial influence even between children is evidently apprehended. A slave's son, though he is also a child, serves his master's baby son, even if he looks more or less like him. Nonetheless, in the end this little baby master is destined to be an outcast and a slave just like this black boy by his colonially arrogant father. Because of her son's skin colour, Désirée is also forsaken by her husband and white society. In the final parts of the story, as Désirée walks away from Armand's house, the slaves picking cotton in the land under the burning sun are spotted, which paints quite an ironic picture symbolising the stark distinction between white and black. This expressly proves the highly oppressive rule of the Aubignys and every other rich family of the southern part of America over the slaves, blacks and the weak. The postcolonial aspects in the story conveyed through female perspective(s) exemplify great material for the new historicist studies searching through the tiny fragments of marginalised humanity.

\section{B. Feminist Aspect}

Feminism is a movement that aims to put women in an equal position with men in the social, political and economical spheres of life. It is set against patriarchy, which is a system of social relationships in which men exploit, dominate and oppress women. Feminism protests against many phenomena, including inequality and difference between the two sexes (Abercombie and Wardel, 2000, p. 193). In fact, feminism declares radically that there is no such thing as sex or gender and that these are socially discursive constructs produced by a male-dominated society. Social feminism states that sexism and biological destiny are indeed learned identities. Then again, Louis Althusser develops Karl Marx's theory on ideologies by explaining how particular positions in society are taken up according to these learned identities (Abercombie and Wardel, 2000, p. 39, p. 208). Feminism has a goal to question the norms and concepts of a male-centred universe and it reflects and thus prevents the social difficulties women confront in real life at the same time (Üzel, 2006, p. 2). It is a reaction that was first started against patriarchy and male repression of women in the 19th century and early 20th century, which is why the movement in this period is called the "First Wave Movement" in feminist history. This activism was carried out for the promotion of equal contracts, parental issues and property rights of women in marriage. Although it turned out to be mostly political in the later decades, the movement remained to be a reaction to men's social, political, economical and domestic domination.

Further, in Désirée's Baby, Chopin depicts the sad situation of white as well as black women and defends their rights by punishing the dominating male figure, Armand, who feels remorseful at the end of the story. To begin with, Désirée is the embodiment of repressed and suffering women in the story. She falls in love with a rich man, Armand, and gets married to him thinking she has started a new life of mutual affection and understanding. No sooner has their honeymoon ended than she discovers Armand's violent and aggressive side due to his prejudiced opinions of slaves. She has a tender and soft feminine heart, "even” towards the blacks, who are smashed under the $19^{\text {th }}$-century colonialist system. Despite her husband's negative qualities, she loves him more and more every day with a wife's commitment. Then, her happiness doubles when she has a baby, as she thinks her family is complete and in bliss. Armand loves her and the baby with all his heart despite his innate violence, and he does not realise the change in the baby boy for a few months. Yet, thanks to her female intuition, Désirée becomes afraid that something unexpected will ruin this happiness, which indeed becomes actualised not much later on. Her son's skin gets darker by every passing day and he grows bigger and bigger, unnaturally for a white baby. Simultaneously, Armand acts 
strangely, as if he is disgusted with her and the baby, which is indeed true. Sensing the evil spirit in her house, she observes the servants' behaviour and Armand's attitude towards them. This frightens her even more as she faces the bitter truth by the time Armand blames her for their son's dark skin, although he himself has dark skin too. Her peaceful life till now has been shattered with this accusation and has awakened her from her dream. She wants to learn the truth about her past by asking her mother, and she is devastated because even her mother calls her back home. She is such a passionate wife that she does not believe Armand will forsake her. But she comprehends she is wrong as he tells her to leave the house because of the baby. Disappointed and hurt, she takes "her" baby and goes her way proudly. She has been psychologically tortured, accused of being a negro, and at the culmination of these hostile attitudes towards her, she is left in the street by her husband. She is quite shaken as she asks for the truth from her mother. "My mother, they tell me I am not white. Armand has told me I am not white. For God's sake tell them it is not true. You must know it is not true. I shall die. I must die. I cannot be so unhappy, and live” (Chopin, 1897, p. 3). Indeed she could stay with her parents again, yet she is too dignified to take this offer. She prefers to live alone in an unknown place than to be cuddled and protected by her parents' secure, loving arms in a prejudiced, enmical and colonial society. As for Armand, he is the perfect representation of an oppressive, unemotional, prejudiced and ungrateful husband. He seems to be in love with Désirée only when things are alright. By marrying her, he promises to love and protect her under any conditions, but he breaks his promise with the first hardship he encounters. Without thinking about his own biological characteristics, he directly blames his wife for the baby or he prefers to blame her rather than himself, which seems like the best option. The baby is hers, not his, as it is black. The society he is living in is already on the side of men, so he can easily be justified for sending Désirée to the streets. After becoming suspicious of his wife's bloodline, he despises her as if he was not the one madly in love with her before. He is also deprived of emotions because he cannot see how deeply his wife loves him when he tells her to go away. It is as if he is a heartless stone and he has no pity for his wife, as it is clearly seen by his attitudes to the slaves. As a man living in America of the 19th century, he has the right to forsake his wife, to take her children or send them away, possess whatever property she has and have another woman, if he likes. Thus, he does whatever society lets him do and deserts his wife and child so quickly and easily. Still, he is punished in the end by fate, when he learns about his mother's true identity and is devastated by the discovery of her letter in which she uncovers the truth. "But, above all," she wrote, "night and day, I thank the good God for having so arranged our lives that our dear Armand will never know that his mother, who adores him, belongs to the race that is cursed with the brand of slavery” (Chopin, 1897, p. 4).

Another woman in the story is Madame Valmondé who looks like she has no serious problems in her own marriage but protects Désirée from any danger, including her husband, Armand. At first, she saves her from the streets by adopting and bringing her up as her daughter. Then, she gives Désirée motherly support in her marriage. Lastly, she shows her sensibility and fondness by welcoming her back to their home. She exemplifies female solidarity by giving emotional, psychological and economic support to her daughter. The last woman character in the story is La Blanche, a black servant working at the Aubignys' house. She works hard, cleans the house and accompanies Madame Aubigny, tending the baby, the little master. She is in a very unlucky position as she is double-repressed, both for being a woman and for being black. As a representative of the colonial system, Monsieur Aubigny ridicules her by despising her skin colour as he talks to Désirée (Chopin, 1897, p. 2). He treats her as he treats every other black woman and man. She is in a worse condition than Désirée just as other black women. In this story, black males including Désirée’s nameless little baby are repressed as women because they are crushed under the same prejudiced social system. 
Shortly, the story reflects the terrible condition of women in the American society of that time and presents a good example for new historicism, as it is from the subject's perspective displaying the centre.

\section{Socialist Aspect}

In the last part of this section, social aspects of the story will be analysed. Socialism is a political ideology which deals with the negative effects of the capitalist system on society. Capitalism justifies every single act carried out for making profit (Verdery, 1996, p. 298). In the story, socialism is depicted by Chopin as a reaction to the colonial and imperial system. White Europeans assume that they can handle those who are economically weaker than themselves and that they are easy to fool and exploit, that they are dependent on others in every way. These people are called slaves, blacks, the colonised and subjects by the capitalist countries. These colonies, and people who come from colonised countries, are impressive sources of resources, profit and money for the colonising countries. In other words, the colonies constitute a great sum of capital for capitalist countries, as Karl Marx says in Das Kapital.

In the story, socialism is observed through class distinction, slavery, colonisation and orphanhood. Class distinction is realised according to money in which the rich are named the upper classes and aristocrats, whereas the poor are named slaves and subjects. In the story, the Valmondé and Aubigny families are members of the upper class whilst servants working in the houses and workers labouring in the fields are at the bottom of society, the slaves. Accordingly, slavery gives an excuse to the master/coloniser to make use of the weak. It strengthens the master's position also, in which the master becomes the centre, the decisionmaker and governor in society. Lastly, orphanhood is an important socialist issue discussed in Chopin's story. Désirée, the female protagonist of the story is an orphan; she was found beside a rock when she was just a little baby. She grows up in a rich family which is from the upper class. However, her orphanhood and ambiguous past turn out to be an obstacle in her social life, such as when she is accused of being black by Armand, and when her father doubts her true family. These people are from the middle class, which is why they place so much importance on her background, and they cannot be sure about the acceptibility of her ancestry in their society. Monsieur Valmondé and Armand Aubigny are doubtful and in fact ashamed that Désirée is an orphan. So, they make an arrangement in which she will get rid of her shameful past by having Armand's surname through marriage. Madame Valmondé appears less prejudiced about the young woman's family, for she sympathises with her as a woman. Yet, as an upper-class woman, she is doubtful enough of her daughter's past which is openly conveyed in her letter to Désirée in which she tells her to leave Armand.

Thereby, taking all these elements into account, a striking social criticism of $19^{\text {th }}$-century America is made for the purpose of altering society, dissolving the long-set class distinctions and eradicating all social prejudices from social life to enable a tolerant atmosphere for human existence and equality.

\section{KATE CHOPIN AS A HUMANIST WRITER}

Ignored like a step-child by mainstream historians, Kate Chopin is in truth a precious literary figure and a pionneer in feminist, postcolonial and socialist works outside the strict rule of the $19^{\text {th }}$-century literary tradition. She shows more courage than many male writers of the time and thus is noted as an important personality (Boren and Davis, 1992, p. 1, 3). For this reason, she is a rich source for those searching for an unheard voice, a novel perspective and a challenging style rather than the well-known English and American literary products. Besides being a case issue for feminists, anthropologists, postcolonialists, modernists and 
postmodernists, Chopin and her works are dissected by new historicists for being innovative, wide-ranging and comprehensive (Walker, 2001, p. 6).

As a feminist writer, Chopin records what was indeed experienced and suffered by women and kept quiet by the patriarchal system in that period. Through Désirée, she reflects her own hard life and the expectations of every single woman living in America. In her personal life, Chopin was a widow whose husband's untimely death left her and their children in a miserable, hopeless condition. Knowing she has no other way to earn a living, Chopin starts writing and promptly discovers her great literary talent. Writing has given her a great opportunity to be a mirror of society, reflecting everything in its most candid state. Being a woman herself, she firstly defends the rights of women. Chopin writes such sad and pathetic stories as Désirée's Baby to display the real condition of women at the time and raise social awareness of their suffering. It is possible to interpret that she must have been really effective and successful, which is why the centre, the history and the canon did not dare include her in the mainstream. For her time and the literary/historical tradition of the time, she is almost an anarchist, a dissident and an alien who consistently writes on marginal issues, whereas she is so noteworthy in new historicism for the very same reason.

What is more, Chopin is even gallant as she portrays the colonial life in the $19^{\text {th }}$-century South. There is the American Civil War approaching which shall break out for motives of colonialism, the slave trade and the huge wealth gap between North and South. Despite this tense atmosphere, she feels it is her duty to raise postcolonial consciousness in society and provide betterment of the black Americans' situation this way. She places La Blanche, other black servants and workers in Désirée's Baby and her other works as representatives of black people in real life. Being a white American citizen, Chopin senses that she can indeed make their feeble voices heard. Hence, she makes a great contribution to the honest representation of the history of humanity.

\section{CONCLUSION}

Overall, Kate Chopin is a worthy woman boldly advocating for whoever is stifled and harmed under the imperial, misogynist and capitalist system of America. Thanks to this, she is now regarded as an important, esoteric woman writer by various literary and social research circles. Despite all the inhibitions and filters of the prejudiced history, Chopin has succeeded in surviving in the dusty gaps of the monolithic system. In the end, she became a published author when Désirée's Baby appeared in Vogue in 1893, which was to be published several times later. This openly proves that her works are loved and appreciated by lots of people. Not just in the $20^{\text {th }}$ century but also in the $21^{\text {st }}$ century, her works continue to gain attention. In this way, Chopin gets her reward for everything she did throughout her life, by at last being given a justified place in history.

\section{Works cited:}

Abercombie, N. - Wardel, A. 2000. The Contemporary British Society Reader. Manchester: Manchester University Press.

Boren, L. - Davis, S. 1992. Kate Chopin Reconsidered: Beyond the Bayou. Baton Rogue: Louisiana State UP.

Chakrabarty, D. 2000. Postcolonial Thought and Historical Difference. England: Princeton University Press.

Chopin, K. 1897. “Désirée’s Baby”. America: Vogue. <www. katechopin.org> Accession: 10. 12. 2012.

Gallagher, C. - Greenblatt, S. (2000). Practicing New Historicism. London: University of Chicago

Press.

Pattee, F. L. 1915. A History of American Literature Since 1870. Cambridge: Harvard University Press. 
Pieters, J. 2001. Moments of Negotiation. Amsterdam: Amsterdam University Press.

Said, E. 1978. Orientalism. New York: Vintage Books.

Üzel, E. 2006. Feminizm ve Doğa Ekseninde Feminizm. Ankara Üniversitesi Sosyal Bilimler Enstitüsü Kamu Yönetimi ve Siyaset Bilimi Anabilim Dalı, (MA Thesis).

Verdery, K. 1996. What Was Socialism, and What Comes Next? Princeton: Princeton University Press. Walker, N. 2001. A Literary Life. Hampshire: Palgrave Macmillan.

\section{Kübra Baysal}

Kastamonu Üniversitesi Yabancı Diller Bölümü Fazıl Boyner Sağlık Yüksekokulu 3. Kat Kuzeykent/Kastamonu

Türkiye

kbaysal@kastamonu.edu.tr 